\title{
The protective effect of ClinOleic against post-surgical adhesions
}

\author{
Yüksel Altınel, M.D., ${ }^{1}$ Ersoy Taşpınar, M.D., ${ }^{1}$ Halil Özgüç, M.D., ${ }^{1}$ \\ Ersin Öztürk, M.D., ${ }^{1}$ Elif Ülker Akyıldız, M.D., ${ }^{2}$ Deniz Bağdaş, M.D. ${ }^{3}$ \\ ${ }^{1}$ Department of General Surgery, Uludag University Faculty of Medicine, Bursa; \\ ${ }^{2}$ Department of Pathology, Uludag University Faculty of Medicine, Bursa; \\ ${ }^{3}$ Uludag University Faculty of Medicine, Experimental Animals Breeding and Research Center, Bursa
}

\begin{abstract}
BACKGROUND: Although the English-language literature is full of studies about post-surgical adhesions, no definitive method has yet been identified to prevent them. The goal of this study was to investigate the effect of ClinOleic on reducing post-surgical adhesion formation.

METHODS: Surgery was performed on 40 adult female Sprague-Dawley rats that were randomly assigned to receive either intraperitoneal ClinOleic, which was used to mimic chyle (ClinOleic group), soybean oil (soybean oil group), olive oil (olive oil group), or $0.9 \% \mathrm{NaCl}$ suspension (control group). All rats underwent laparotomy, side-wall and cecal abrasion, and primary closure. On the 30th day following surgery, rats were sacrificed and examined using the Majuzi adhesion classification and histopathological grading scales.
\end{abstract}

RESULTS: The adhesion and histopathological scores of the ClinOleic group were significantly lower compared to the control group $(0.9 \% \mathrm{NaCl})(\mathrm{p}<0.05)$. A statistically significant decrease in fibrosis was observed in the soybean and olive oil groups when compared to the control group $(p<0.05)$. However, the adhesion grades of the ClinOleic, soybean and olive oil groups were comparable. We did not observe any post-surgical adhesions in the ClinOleic group.

CONCLUSION: The parenteral nutrition solution ClinOleic may be an effective and readily available agent for the prevention of post-surgical adhesions.

Key words: Abdominal surgery; adhesion prevention; ClinOleic; intra-abdominal adhesions.

\section{INTRODUCTION}

Adhesion formation following surgery remains an almost inevitable consequence of most abdominal procedures. After multiple operations, the incidence of intra-abdominal adhesions could be as high as $95 \%$. Advancements in surgical techniques, such as laparoscopy, can help to diminish the probability of post-surgical adhesions. ${ }^{[1]}$ Despite the decrease in the adhesion formation rate from $50 \%$ after laparotomy to $12 \%$ after laparoscopy, surgery for adhesions may still be required

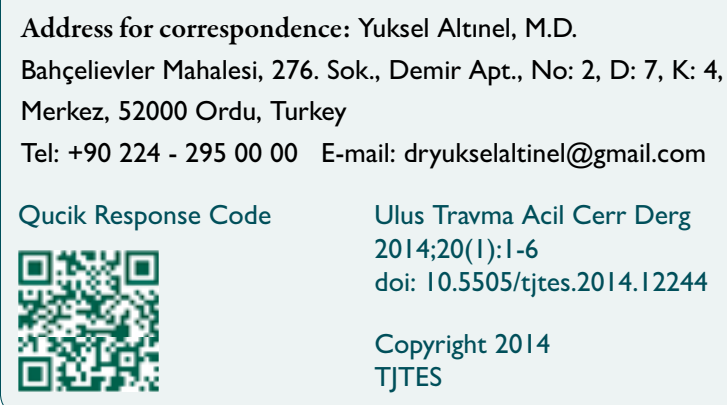

after these surgeries. ${ }^{[2,3]}$ Post-surgical adhesions can lead to a broad range of diseases, such as infertility, pelvic pain, bowel obstruction, difficulties during re-operations, and increased morbidity and mortality. ${ }^{[4-6]}$ Many adjuvants that prevent inflammation (steroidal and non-steroidal anti-inflammatory medications), degrade fibrin (recombinant tissue plasminogen activator [t-PA]), or act as barriers (absorbable material/ solution/gel or liquid paraffin) have been evaluated to prevent post-surgical adhesions. ${ }^{[7-9]}$ Nevertheless, no definitive method or agent has been proven to prevent the formation of post-surgical adhesions.

Chyle, a milky bodily fluid consisting of lymph and free fatty acids (FFAs), is formed in the small intestine during the digestion of fatty foods and is taken up by lymphatic vessels. ${ }^{[10]}$ In our clinical practice, we have observed that patients who had gastrointestinal surgery with extensive lymphatic dissection did not develop post-surgical adhesions often. This led us to hypothesize that chyle may have acted as a preventive factor against adhesion formation. Therefore, we conducted this study using the parenteral nutrition product ClinOleic (Baxter, UK $)^{[I I]}$ to model human chyle in rats. 
This study examines the effect of ClinOleic and a few other oils on reducing adhesion formation in rats. Our hypothesis was that chyle draining into the peritoneal cavity after gastrointestinal surgery would prevent adhesion formation.

\section{MATERIALS AND METHODS}

\section{Materials}

ClinOleic (Baxter, United Kingdom) is a mixture of $80 \%$ olive oil and $20 \%$ soybean oil. It is used as a parenteral lipid emulsion for supplemental nutrition in patients with intestinal failure (Table I)..$^{[12,13]}$

Soybeans consist of soy protein, isoflavones, fibers, and saponins. Soybean oil is a long-chain triglyceride with two dominant fatty acid residues: $25 \%$ oleic acid and $51 \%$ linoleic acid (omega-6). It also includes methyl methacrylate, palmitic acid, linolenic acid (omega-3), and stearic acid residues. Many soy ingredients have potential health benefits for patients. ${ }^{[1,15]}$

Olive oil has long been recognized for its unusual fat content. This plant oil is one of the few widely used culinary oils that contain approximately $75 \%$ oleic acid (a monounsaturated, omega-9 fatty acid) and $21 \%$ linoleic and linolenic acid. Olive oil that has undergone less processing also comprises $\alpha$-tocopherol (an antioxidant and anti-inflammatory agent), squalene, phytosterols, triterpenes, and phenolic compounds. ${ }^{[16,17]}$

All the fluids used in this study were sterilized prior to the surgical procedures.

\section{Animals}

The approval for this study was given by the Medical Faculty of Uludağ University, Experimental Animals Production and Research Laboratory Ethical Committee. The protocols were in compliance with the conditions governing the care and use of laboratory animals (Declaration of Helsinki).

Forty adult female Sprague-Dawley rats, 3-4 months of age and weighing 350-400 grams, were used. Cages measuring $40 \times 25 \times 25 \mathrm{~cm}$ with plastic sides and bottoms covered with stainless woven wire were used. Wood shavings on the floor of the cages were replaced every two days. A maximum of five rats were kept in each cage under standard laboratory conditions, with water in drinking bottles and a pellet food manufactured specially for rats provided. They were housed at a temperature of $20-22{ }^{\circ} \mathrm{C}$, relative humidity of $50-60 \%$ and with 12-hour light-dark cycles. The rats were divided into four groups.

\section{Surgical Procedures}

All animals were fasted overnight prior to surgery and were anesthetized in jars. Anesthesia was maintained with an injection of a combination of $10 \mathrm{mg} / \mathrm{kg}$ intramuscular ketamine $\left(\right.$ Ketalar $\left.^{\circledR}\right)$ and I ml/kg xylazine (Rompun ${ }^{\circledR}$ ). Antibiotics were not administered prior to incision. All surgical procedures were performed under sterile conditions.

Following povidone iodine application to the skin, a $4 \mathrm{~cm}$ midline abdominal incision was made. The cecum and the terminal ileum were grasped and scraped with sterile dry gauze. After the injured cecum was returned to the intraperitoneal

Table I. Compounds of $20 \%$ ClinOleic (per $100 \mathrm{ml}$ ) lipid emulsion

\begin{tabular}{ll}
\hline Ingredients & Amount \\
\hline Purified olive oil (80\%) and soybean oil (20\%) & $20 \mathrm{~g}$ \\
Purified egg phosphatides & $1.2 \mathrm{~g}$ \\
Glycerol & $2.25 \mathrm{~g}$ \\
Sodium oleate & $0.03 \mathrm{~g}$ \\
Sodium hydroxide & As needed for Ph adjustment \\
Water for injection & Sufficient quantity \\
\hline
\end{tabular}

Table 2. Adhesion grading according to Majuzi classification

\begin{tabular}{ll}
\hline Grade & Description of Grade \\
\hline 0 & No adhesion \\
1 & Very small, irregular adhesion \\
2 & Easily separable medium intensity adhesion \\
3 & Intense, not easily separable regular adhesion \\
4 & Very intense, not easily separable, homogeneous adhesion \\
\hline
\end{tabular}


Table 3. Inflammation grading scale

\begin{tabular}{ll}
\hline 0 & Nil \\
\hline & Grant cells, occasional scattered lymphocytes and \\
& plasma cells \\
2 & $\begin{array}{l}\text { Grant cells with increased numbers of admixed } \\
\text { lymphocytes, plasma cells, eosinophils, neutrophils } \\
3\end{array}$ \\
& Many admixed inflammatory cells, micro abscesses \\
& present
\end{tabular}

Table 4. Fibrosis grading scale

\begin{tabular}{ll}
\hline 0 & Nil \\
1 & Minimal, loose \\
2 & Moderate \\
3 & Florid, dense \\
\hline
\end{tabular}

cavity, a $2 \times 2 \mathrm{~cm}$ apposing parietal and visceral peritoneal abrasion was performed using dry gauze. After the procedure, 5 $\mathrm{ml} 0.9 \% \mathrm{NaCl}$ suspension was added into the peritoneal cavity of rats in the control group (Group I), 5 cc of soybean oil was added into the peritoneal cavity of rats in the soybean oil group (Group 2), 5 cc of olive oil was added into the peritoneal cavity of rats in the olive oil group (Group 3), and $5 \mathrm{cc}$ ClinOleic was added into the peritoneal cavity of rats in the ClinOleic group (Group 4). The abdominal fascia was closed using a continuous technique with 000 polypropylene suture. The skin was closed with a surgical stapler.

\section{Evaluation of Adhesion Formation}

On the 30th postoperative day, the rats were sacrificed by cervical dislocation. Through the initial laparotomy scar, the abdomen was opened using a midline incision from cranial to caudal to view the extent of intra-abdominal adhesion formation. The adhesions were graded according to the Majuzi classification system ${ }^{[18]}$ by an experienced surgeon of the clinic who was blinded to the different treatment groups (Table 2).

\section{Morphologic Evaluation}

The $2 \times 2 \mathrm{~cm}$ area of abrasion in the right lower quadrant was excised en-bloc. A pathologist, who was uninformed regarding the methods and groups, examined the damaged abdominal wall of each rat. Through this examination, the interactions of the oily fluids with the peritoneum and the efficacy of these fluids in preventing adhesions were observed. The tissues were fixed in a $10 \%$ buffered formaldehyde solution and embedded in paraffin following dehydration. Tissue sections of 5 $\mu \mathrm{m}$ thickness were obtained and stained with hematoxylin and eosin. These sections were evaluated using light microscopy at a magnification of 100x. The histopathological grade was measured with a semi-quantitative scoring system (Tables 3 , 4). Vascular proliferation was scored as follows: 0 , no vascular proliferation; I, mild vascular proliferation; 2, moderate vascular proliferation; and 3, intense vascular proliferation. ${ }^{[19,20]}$

\section{Statistical Analysis}

Adhesion and histopathological scores did not always follow normal distributions. Thus, statistical inferences were made using Mann-Whitney U-tests and the Statistical Package for the Social Sciences (SPSS) 10.0 software (Chicago, IL). A p value $<0.05$ on a two-tailed test was considered statistically significant. The Kruskal-Wallis test for intergroup comparisons was used to evaluate the data.

\section{RESULTS}

No rat died during or after surgery in this experiment. There were no signs of clinical inflammation on the incision in any rats. When comparing adhesion grades (Table 5), a significant difference was observed between the control and ClinOleic groups $(p<0.05)$. However, the soybean oil and olive oil groups did not show any significant differences compared to the control group. Additionally, the adhesion grades of the ClinOleic, soybean oil and olive oil groups were comparable. We did not observe any post-surgical adhesions in the ClinOleic group (Fig. Ia).

The median histopathological fibrosis, inflammation and vascular proliferation scores of the ClinOleic group were significantly lower than of the control group $(p<0.05)$, but were comparable to the soybean oil group and olive oil group (Fig Ib-d). The histopathological fibrosis score of the control group was significantly higher compared to both the soybean oil group and olive oil group $(p<0.05)$ (Table 6).

Table 5. Postoperative adhesion grades of groups and histopathological features of biopsies from the peritoneum

\begin{tabular}{lccccc}
\hline & I-Control & 2-Soybean oil & 3-Olive oil & 4-ClinOleic & p \\
\hline Adhesion grade & $\mathrm{I} .5(0-3)$ & $0(0-2)$ & $0(0-2)$ & $0(0-0)$ & $0.023^{*}$ \\
Fibrosis & $\mathrm{I}(0-3)$ & $0(0-1)$ & $0(0-1)$ & $0(0-0)$ & $<0.05^{* *}$ \\
Inflammation & $\mathrm{I} .5(0-3)$ & $0(0-2)$ & $0(0-1)$ & $0(0-0)$ & NS \\
Vascular proliferation & $\mathrm{I}(0-2)$ & $0(0-2)$ & $0(0-1)$ & $0(0-0)$ & NS \\
\hline
\end{tabular}

* Group 4 was significantly lower than the control group $(p<0.05)$.

** Soybean and olive oil groups $(p=0.043)$ and ClinOleic group $(p=0.023)$ were significantly lower than the control group. 

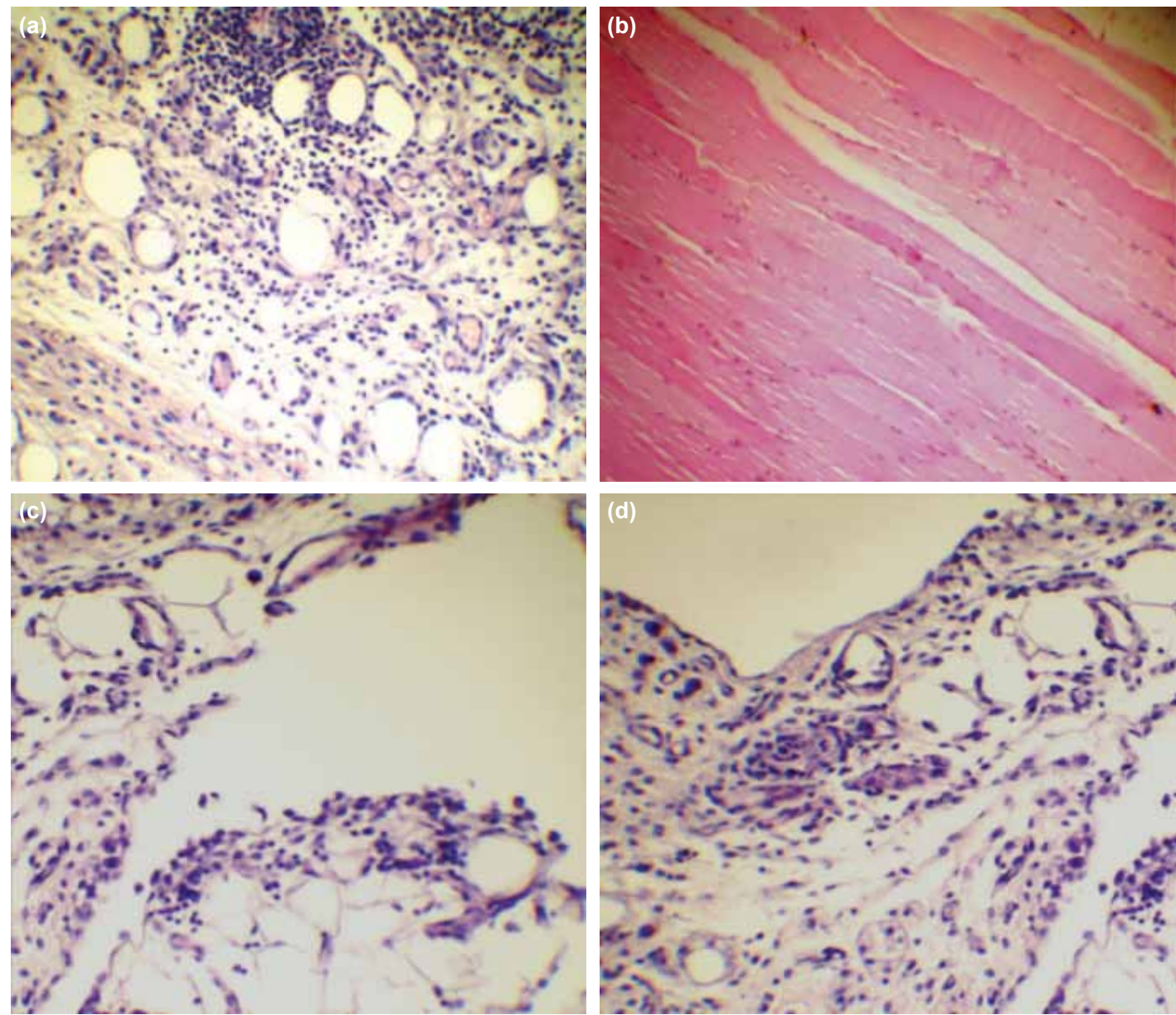

Figure 1. (a) Oil vacuoles of the ClinOleic group (hematoxylin \& eosin [H\&E]). (b) Peritoneum of the control group (H\&E). (c) Oil vacuoles of the soybean oil group (H\&E). (d) Oil vacuoles of the olive oil group (H\&E).

\section{DISCUSSION}

In this experimental study modeling intra-abdominal adhesions in rats, adhesions were diminished when ClinOleic was applied into the intraperitoneal cavity. Despite some similar effects when other oil products were used, the greatest improvement was observed when ClinOleic was used. This finding has encouraged us to repeat this study in humans.
In this study, we investigated ClinOleic and its additives. Soybeans are associated with low levels of inflammatory markers and enhanced endothelial function; however, the exact mechanisms of these activities are not known. ${ }^{[15,21,22]}$ Olive oil is the main component of ClinOleic. Hydroxytyrosol and polyphenol are believed to be the main antioxidant compounds in olive oil and contribute significantly to the many health benefits of this oil. Oleic acid and phenolic compounds

Table 6. Statistical comparison of the groups according to the adhesion, fibrosis, inflammation, and vascular proliferation grades

\begin{tabular}{lcccc}
\hline Groups & \multicolumn{3}{c}{ p-value } \\
\cline { 2 - 5 } & Adhesion & Fibrosis & Inflammation & Vascular proliferation \\
\hline Group I vs. Group 2* & 0.12 & 0.043 & 0.16 & 0.39 \\
Group I vs. Group 3** & 0.08 & 0.043 & 0.06 & 0.10 \\
Group I vs. Group 4*** & 0.023 & 0.023 & 0.023 & 0.023 \\
Group 2 vs. Group 3 & 0.73 & I & 0.63 & 0.63 \\
Group 2 vs. Group 4 & 0.28 & 0.73 & 0.28 & 0.28 \\
Group 3 vs. Group 4 & 0.48 & 0.73 & 0.48 & 0.48 \\
\hline
\end{tabular}

*, ** Soybean and olive oil groups were significantly lower than the control group $(p<0.05)$.

*** ClinOleic group was significantly lower than the control group $(p<0.05)$. 
exert anti-inflammatory and anti-thrombotic activities. Hydrocarbons, polyphenols, tocopherols, sterols, triterpenoids, and other components of olive oil usually exert beneficial effects on vascular dysfunction by modulating the mechanisms of endothelial activity. Such mechanisms involve the release of nitric oxide, eicosanoids (prostaglandins and leukotrienes) and adhesion molecules. In most cases, the release of these molecules is promoted by the activation of nuclear factor $\kappa B$ by reactive oxygen species. ${ }^{[23]}$ Several in vitro studies have shown that ClinOleic may interfere less with inflammatory responses, including monocyte, lymphocyte, and neutrophil responses, than soybean oil. ${ }^{[2]}$

However, the preventive effect of ClinOleic may be linked to its barrier effect. Many pharmacologic agents in the form of liquids, gels and solids have been implicated in the prevention of intra-abdominal adhesions. These agents are believed to act as mechanical barriers between peritoneal surfaces, and include agents such as modified chitosan-dextran gel, ${ }^{[25]}$ nitric oxide, a Chinese medicinal compound known as Changtong oral liquid, ${ }^{[7]}$ intravenous melatonin, ${ }^{[2]}$ a combination of t-PA and phosphatidylcholine, ${ }^{[26]}$ and poly(ethylene glycol)-poly $(\varepsilon-$ caprolactone)-poly(ethylene glycol) (PEG-PCL-PEG, PECE) hydrogel. ${ }^{[6]}$ Previously evaluated adhesion barriers include Seprafilm ${ }^{\circledR} \|{ }^{[19]}$ and polyethylene glycol spray (SprayGel). ${ }^{[27]}$ In an experimental study by Schreinemacher et al., ${ }^{[28]}$ the authors reported that polypropylene mesh with an omega-3 fatty acid barrier coating, C-Qur (Ethicon Inc., Somerville, NJ, USA), reduced adhesion formation to intraperitoneal mesh in the short term, but the effect diminished in the long term. Phagocytosis of absorbable coatings may have contributed to adhesion formation.

Ferric hyaluronate gel has also been investigated and was found to lead to a $69 \%$ reduction in intra-abdominal adhesion formation. This was due to an increase in viscosity caused by the ferric ions. ${ }^{[2]}$ Conversely, another animal study demonstrated that no significant prevention of adhesions was observed with this compound. ${ }^{[3]}$

Highly viscous liquids may prevent adhesion formation by forming a layer between surfaces, thereby preventing any contact of the de-peritonealized surface with the surrounding tissues. In vitro studies showed that, in a highly viscous medium, the movement of cells or cell groups towards each other is delayed and adhesion either does not occur or is delayed, depending on the viscosity. ${ }^{[30-32]}$ Aysan et al. performed many different studies regarding the prevention of peritoneal adhesions. These included using soybean oi ${ }^{[14]}$ before peritoneal trauma, using honey, which has a dense and complex chemical composition, ${ }^{[33]}$ and using viscous $6 \%$ hydroxy ethyl starch (HES) solution. ${ }^{[34]}$ When the viscosity of the fluid inserted into the intraperitoneal cavity was increased, the reduction of intra-abdominal adhesion formation was achieved by an unknown viscosity-dependent process. ${ }^{[34]}$

In summary, the preventive effect of ClinOleic may be due to the anti-inflammatory effects of its olive oil component or to its barrier effect. Because the results of the ClinOleic group were improved relative to its additive groups (olive oil and soybean oil groups), the net effect may not be linked only to the anti-inflammatory effects of olive oil. It is likely that more than one mechanism is responsible for the protective effect of ClinOleic against post-surgical adhesions. Nevertheless, ClinOleic showed a significant anti-adhesive property in our rat model and has encouraged us to perform human studies.

According to our encouraging results, ClinOleic may act as an anti-adhesive material, which is a very important clinical gain for patients undergoing abdominal surgery. Among the many materials used in animal adhesion studies, ClinOleic seems to be the option most preferred for use in humans. Additionally, our study may lead to some new trends. For instance, the use of intra-abdominal drains could be questioned. Using energy devices in dissecting the mesentery of hollow viscus could also be reconsidered. Additionally, the effect of early enteral feeding may not only prevent translocation of bacteria from the intestines, but may also cause the formation of more chyle in the intraperitoneal cavity.

To the best of our knowledge, this is a novel study that attempts to examine the effect of chyle on preventing intraabdominal adhesions. In this report, we present a useful antiadhesive material for gastrointestinal surgeons that can be applied in everyday practice, and our encouraging results also offer many other findings and ideas in the field.

\section{Acknowledgements}

This study was not funded by any company or institution. This study was presented in the Congress of the 47th ESSR 2012.

\section{Ethical standards}

The experiments complied with the current laws of Turkey.

Conflict of interest: None declared.

\section{REFERENCES}

1. Lauder CI, Garcea G, Strickland A, Maddern GJ. Abdominal adhesion prevention: still a sticky subject? Dig Surg 2010;27:347-58. CrossRef

2. Hatipoğlu A, Türkyilmaz Z, Mert S. The effects of melatonin on postoperative intraabdominal adhesion formation. Yonsei Med J 2007;48:659-64.

3. Detchev R, Bazot M, Soriano D, Daraï E. Prevention of de novo adhesion by ferric hyaluronate gel after laparoscopic surgery in an animal model. JSLS 2004;8:263-8.

4. Hunt T, Gimbel M. Postoperative adhesive disease. Perspect Colon Rectal Surg 1998;11:83-91.

5. Alpay Z, Saed GM, Diamond MP. Postoperative adhesions: from formation to prevention. Semin Reprod Med 2008;26:313-21. CrossRef

6. Yang B, Gong C, Qian Z, Zhao X, Li Z, Qi X, et al. Prevention of postsurgical abdominal adhesions by a novel biodegradable thermosensitive PECE hydrogel. BMC Biotechnol 2010;10:65. CrossRef

7. Yang XX, Shi HP, Hou LB. Chinese medicine compound Changtong oral liquid on postoperative intestinal adhesions. World J Gastroenterol 2005;11:2967-70.

8. Topal E, Ozturk E, Sen G, Yerci O, Yilmazlar T. A comparison of three fibrinolytic agents in prevention of intra-abdominal adhesions. Acta Chir Belg 2010;110:71-5.

9. Ozturk E, Yilmazlar A, Berhuni S, Yilmazlar T. The effectiveness of local anesthetics in preventing postoperative adhesions in rat models. Tech Coloproctol 2010;14:337-40. CrossRef 
10. Whang EE, Ashley SW, Zinner MJ. Small intestine. In: Brunicardi FC, Andersen DK, Billiar TR, et al., eds. 8th ed. Schwartz's principles of surgery. New York, NY: McGraw-Hill; 2005. p. 1017-54.

11. Product insert for $20 \%$ ClinOleic ${ }^{\circledast}$. PL. 0116/0313 RA.785. Norfolk, UK: Baxter Healthcare; 2003.

12. Gonyon T, Carter PW, Dahlem O, Denet AR, Owen H, Trouilly JL. Container effects on the physicochemical properties of parenteral lipid emulsions. Nutrition 2008;24:1182-8. CrossRef

13. Thomas-Gibson S, Jawhari A, Atlan P, Brun AL, Farthing M, Forbes A. Safe and efficacious prolonged use of an olive oil-based lipid emulsion (ClinOleic) in chronic intestinal failure. Clin Nutr 2004;23:697-703.

14. Aysan E, Bektas H, Kaygusuz A, Huq GE. A new approach for decreasing postoperative peritoneal adhesions: preventing peritoneal trauma with soybean oil. J Invest Surg 2009;22:275-80. CrossRef

15. Esposito K, Giugliano D. Diet and inflammation: a link to metabolic and cardiovascular diseases. Eur Heart J 2006;27:15-20. CrossRef

16. Sala-Vila A, Barbosa VM, Calder PC. Olive oil in parenteral nutrition. Curr Opin Clin Nutr Metab Care 2007;10:165-74. CrossRef

17. Covas MI, Ruiz-Gutierrez V, de la Torre R, et al. Minor components of olive oil: Evidence to date of health benefits in humans. Nutr Rev 2006;64:20-30. CrossRef

18. Mazuji MK, Kalambaheti K, Pawar B. Prevention of adhesions with polyvinylpyrrolidone. Preliminary report. Arch Surg 1964;89:1011-5.

19. Irkorucu O, Ferahköşe Z, Memiş L, Ekinci O, Akin M. Reduction of postsurgical adhesions in a rat model: a comparative study. Clinics (Sao Paulo) 2009;64:143-8.

20. Hooker GD, Taylor BM, Driman DK. Prevention of adhesion formation with use of sodium hyaluronate-based bioresorbable membrane in a rat model of ventral hernia repair with polypropylene mesh--a randomized, controlled study. Surgery 1999;125:211-6. CrossRef

21. Steinberg FM, Guthrie NL, Villablanca AC, Kumar K, Murray MJ. Soy protein with isoflavones has favorable effects on endothelial function that are independent of lipid and antioxidant effects in healthy postmenopausal women. Am J Clin Nutr 2003;78:123-30.

22. Azadbakht L, Kimiagar M, Mehrabi Y, Esmaillzadeh A, Hu FB, Willett WC. Soy consumption, markers of inflammation, and endothelial function: a cross-over study in postmenopausal women with the metabolic syndrome. Diabetes Care 2007;30:967-73. CrossRef
23. Perona JS, Cabello-Moruno R, Ruiz-Gutierrez V. The role of virgin olive oil components in the modulation of endothelial function. J Nutr Biochem 2006;17(7):429-45. CrossRef

24. Buenestado A, Cortijo J, Sanz MJ, Naim-Abu-Nabah Y, Martinez-Losa M, Mata M, et al. Olive oil-based lipid emulsion's neutral effects on neutrophil functions and leukocyte-endothelial cell interactions. JPEN J Parenter Enteral Nutr 2006;30:286-96. CrossRef

25. Lauder CI, Garcea G, Strickland A, Maddern GJ. Use of a modified chitosan-dextran gel to prevent peritoneal adhesions in a rat model. J Surg Res 2011;171:877-82. CrossRef

26. Ferland R, Mulani D, Campbell PK. Evaluation of a sprayable polyethylene glycol adhesion barrier in a porcine efficacy model. Hum Reprod 2001;16:2718-23. CrossRef

27. Hellebrekers BW, Trimbos-Kemper GC, van Blitterswijk CA, Bakkum EA, Trimbos JB. Effects of five different barrier materials on postsurgical adhesion formation in the rat. Hum Reprod 2000;15:1358-63. CrossRef

28. Schreinemacher MH, Emans PJ, Gijbels MJ, Greve JW, Beets GL, Bouvy ND. Degradation of mesh coatings and intraperitoneal adhesion formation in an experimental model. Br J Surg 2009;96:305-13. CrossRef

29. Lundorff P, van Geldorp H, Tronstad SE, Lalos O, Larsson B, Johns DB, et al. Reduction of post-surgical adhesions with ferric hyaluronate gel: a European study. Hum Reprod 2001;16:1982-8. CrossRef

30. Wallwiener M, Brucker S, Hierlemann H, Brochhausen C, Solomayer E, Wallwiener C. Innovative barriers for peritoneal adhesion prevention: liquid or solid? A rat uterine horn model. Fertil Steril 2006;86(4 Suppl):1266-76. CrossRef

31. diZerega GS, Cortese S, Rodgers KE, Block KM, Falcone SJ, Juarez TG, et al. A modern biomaterial for adhesion prevention.J Biomed Mater Res B Appl Biomater 2007;81:239-50. CrossRef

32. Folger R, Weiss L, Glaves D, Subjeck JR, Harlos JP. Translational movements of macrophages through media of different viscosities. J Cell Sci 1978;31:245-57.

33. Aysan E, Ayar E, Aren A, Cifter C. The role of intra-peritoneal honey administration in preventing post-operative peritoneal adhesions. Eur J Obstet Gynecol Reprod Biol 2002;104:152-5. CrossRef

34. Aysan E, Basak F, Kinaci E, Yanar H, Coskun H. Experimental adhesion model: effect of viscosities of fluids put in the peritoneal cavity on preventing peritoneal adhesions. Exp Anim 2007;56:349-54. CrossRef

\section{DENEYSEL ÇALIŞMA - ÖZET}

\section{Cerrahi sonrası oluşan karıniçi yapışıklıklara karşı ClinOleic' in koruyucu etkinliği Dr. Yüksel Altınel, ${ }^{1}$ Dr. Ersoy Taşpınar, ${ }^{1}$ Dr. Halil Özgüç, ${ }^{1}$ Dr. Ersin Öztürk, ${ }^{1}$ Dr. Elif Ülker Akyıldız, ${ }^{2}$ Dr. Deniz Bağdaş ${ }^{3}$}

${ }^{1}$ Uludağ Üniversitesi Tip Fakültesi, Genel Cerrahi Anabilim Dalı, Bursa;

${ }^{2}$ Uludağ Üniversitesi Tip Fakültesi, Patoloji Anabilim Dalı, Bursa;

${ }^{3}$ Uludağ Üniversitesi Tip Fakültesi, Deney Hayvanları Araştırma Merkezi, Bursa

AMAÇ: Karıniçi yapışıklıklar morbiditenin önemli bir sebebi olmaya ve tedavi maliyetinin artmasına neden olmaktadır. Bu çalışmada, abdominal cerrahi sonrasında yapışıklıkları önlemede bir parenteral beslenme ürünü olan ClinOleic'in intraperitoneal kullanımının yapışıklık oluşumuna etkisi araştıııldı.

GEREÇ VE YÖNTEM: Rastgele seçilen 40 yetişkin Sprague-Dawley cinsi sıçana anestezi altında laparatomi yapıldı ve karın yan duvarı ve çekumda abrazyon oluşturuldu. Peritoneal boşluğa grup l'de (kontrol grubu) \%0.9 NaCl çözeltisi, grup 2'de soya yağı, grup 3'de zeytin yağı, grup 4'de ClinOleic uygulandı. Daha sonra karın primer kapatıldı. Deneyin 30. gününde sıçanlar öldürüldü. Gruplarda yapışıklık miktarı kör olarak makroskopik değerlendirme Majuzi skalasına göre, histopatolojik değerlendirme ise semikantitatif skorlama sistemlerine (enflamasyon grade skalası, fibrozis grade skalası ve vasküler proliferasyon grade skalası) göre ölçüldü.

BULGULAR: Makroskopik olarak yapışıklık derecesi grup I ile karşılaştıııldığında grup 4'de anlamlı olarak düşüktü ( $p<0.005)$. Grup 4'de cerrahi sonrası yapışıklık görülmedi. Grup 2, 3 ile grup 4 arasında yapışıklık derecesi açısından istatistiksel fark saptanmadı. Histopatolojik skorlar ise grup I ile karşılaştıııldığında grup 4'de belirgin olarak düşüktü $(p<0.005)$. Grup 2, 3 ile grup 4 arasında histopatolojik anlamlı fark saptanmadı. TARTIŞMA: Parenteral beslenme ürünü olan ClinOleic'in intraperitoneal kullanımı deneysel şartlarda karıniçi yapışıklıkları önlemede başarılı bulunmuştur. Klinikte de rahatıkla uygulanabilecek bu yöntemin daha fazla klinik çalısmaya ihtiyacı vardır.

Anahtar sözcükler: Abdominal cerrahi; yapışılık önleyici; ClinOleic; karıniçi yapışılık. 